\title{
Education as a correlate of life satisfaction among formal sector retirees in Lagos State, Nigeria
}

\author{
Bola Amaike \\ Department of Sociology, Faculty of Social Sciences, University of Lagos, Nigeria \\ Mobile: +234(8053064761) \\ Email: bolaamaike@yahoo.com; gamaike@unilag.edu.ng
}

\begin{abstract}
The effect of education on life satisfaction among formal sector retirees in Lagos State was assessed to determine its impact on life adjustment in retirement. The study also examined the effects of education on selfrated health and well-being of formal sector retirees. Life course perspective, dependency theory, modernization theory of ageing and wealth flow theory were adopted for the theoretical framework. Using a multistaged systematic sampling method, retirees from the public sector and organized private sector were covered through questionnaire and structured interviews. Questionnaires were administered on I32I retirees while 20 in-depth interviews were conducted for executive members of pensioners' unions and pension managers. Older retirees with at least secondary education had better living conditions and reported higher life satisfaction than their counterparts with lower educational qualifications. The paper concludes with a policy implication, stressing the importance of income security and life skills to retirement planning and life satisfaction in retirement.
\end{abstract}

Key words: Retirement, quality of life, education, retirees, ageing.

\section{Résumé}

L'effet de l'éducation sur la satisfaction de la vie des retraités du secteur formel de l'État de Lagos a été évalué pour déterminer son impact sur l'adaptation de la vie à la retraite. L'étude a également examiné les effets de l'éducation sur la santé auto-évaluée et le bien -être des retraités du secteur formel. Perspective de parcours de vie, théorie de la dépendance, la théorie de la modernisation du vieillissement et de la théorie des flux de richesses ont été adoptés comme cadre théorique. En utilisant une méthode d'échantillonnage systématique en plusieurs étapes, les retraités du secteur public et du secteur privé organisé ont été couverts par des interviews par questionnaire et structurée. Questionnaire a été administré à I 32 I retraités et 20 entrevues approfondies ont été menées pour les membres exécutifs des unions de retraités et les gestionnaires de régimes de retraite. Retraités âgés ayant fait des études secondaires au moins avaient de meilleures conditions de vie et ont exprimé leur satisfaction de vie plus longue par rapport à leurs homologues moins qualification pédagogique. Le document conclut avec implication politique soulignant l'importance de la sécurité du revenu et les compétences de vie à la planification de la retraite et la satisfaction de vie à la retraite.

Mots clés : Retraite, qualité de vie, l'éducation, les retraités, le vieillissement.

\section{Introduction}

Retirement is an important stage in the occupational life cycle of every worker. Retirement is not just a period in the life course, but a process that evolves over time, starting from pre-retirement planning to ongoing adjustment after disengagement (Amaike, 2009; Atchley, 1985). This period is also characterized by a substantial reduction in income with fewer opportunities to remain active and relevant in society (Moody, 2002; Ogunbameru, 2000; Atchley, 1985). Where possible, opportunities to maintain a previous socio-economic status in retirement are dependent on life course events and individuals' previous assets (Hooyman \& Kiyak, 2010; Oishi, et al. 2009; Li \& Liang, 2007; Pinquart \& Sorensen, 2000). These opportunities are influenced by education, which has been identified as one of the determinants of perceived socio-economic well-being and life satisfaction in retirement. Hence, there is a strong correlation between education and life satisfaction (Seligowski et al. 2012; Diener, 1984; Caldwell, 1980). Similarly, education determines opportunities and strategies available to individuals especially in retirement (Bender \& Jivan, 2005; Fonseca, 2008). Since education is closely related to income and both are predictors of life satisfaction, higher education will likely translate to better income, improved living conditions and higher life satisfaction in retirement (Blanchflower \& Oswald, 2004; Price 2002).

Difficulties associated with retirement, which include lower income, reduced social roles and status, often limit retirees' access to material and social resources required to cope with adjustments in 
retirement. This invariably has adverse effects on the quality of life and life satisfaction of older people in retirement. Since education confers on individuals lifelong advantages and appropriate coping strategies (Oishi, et al. 2009; Alpas et al., 2000; Calasanti, 1996), retirees without basic education will face greater challenges in retirement.

In essence, educational attainment does not just determine occupational status and income, but also affects every aspect of a retiree's life! Therefore, a retiree with no or low education (primary) will likely have inadequate (poor) income, be unhealthy and live in precarious situations usually below the poverty level. Many studies on the effects of educational attainment tend to focus on job satisfaction among workers, with less emphasis on its impact on postretirement life (Fonseca, 2008; Li \& Liang, 2007; Bender \& Jivan, 2005; Helliwell \&Putnam, 2004; Pinquart \& Sorensen, 2000, Calasanti, 1996). This gap has necessitated this present study, to explore the effects of education on life satisfaction of formal sector retirees in Lagos State.

\section{Literature review and theoretical framework}

There are many routes to retirement, which also result in different definitions adopted by researchers and respondents. In this study, retirees are defined as older workers who have disengaged from paid employment but are entitled to retirement benefits based on years of service (Amaike, 2009; Moody, 2002; Ogunbameru, 2000). Although there is no consensus among scholars on the exact meanings of retirement, this study took a cue from popular definitions in literature (Cumming \& Henry 196I; Atchley 1985; Ogunbameru 2000; Akeredolu-Ale \& Aribiah, 200I). Retirement is defined as the withdrawal of persons aged 50 years and above from paid employment after a minimum of 10 years of continuous service either in the public or private sector regardless of their current occupational status. Education, on the other hand, is a life-long process which can be formal or informal (Oyekanmi \& Nwabueze, 2006). Education empowers individuals with life skills to achieve their life goals and transform their environment positively (Cunha \& Heckman, 2007; Heckman, Stixrud \& Urzua 2006; Fujita \& Diener, 2005). Generally, educational attainment enhances perceived opportunities of retirees which consequently have positive effects on life satisfaction in retirement (Amaike 2009; Russell 2007; Akeredolu-Ale and Aribiah 200I). One can therefore deduce that well-educated retirees will have adequate income which may translate to better quality of life and higher levels of life satisfaction in retire- ment (Li et al. 20 I3, Alkire \& Foster 20I I; Lou, et al. 2010). Moreover, it has been established that the quantum and quality of resources (livelihood) available to retirees are greatly determined by key factors such as educational attainment, health and income which also affect perceived levels of life satisfaction (Amaike, 2009; Cunha and Heckman 2007; Moody 2002; Moen 200I). Although education is positively related to life satisfaction, there are conflicting views on the predictive power and nature of this relationship (Oishi, et al. 2009; Lee, 2000).

The relationship between educational attainment and life satisfaction is minimal after post-primary education. This is because the transformative power of education has its 'elasticity' which once overstretched by expensive lifestyles or inadequate livelihood strategies due to unemployment can lead to frustration. It is also possible for illiterate retirees to adopt coping strategies which may significantly reduce the challenges of no or low education through skill acquisition or income remittances. This is because every human being, no matter how 'ignorant' is capable of critically assessing his or her situations and adopting strategies or tools to deal with their personal and social reality (Freire, 1996; 1970). With critical self-awareness and the right assessment, illiterate adults can learn and indeed transform their 'lived' experiences. To Freire (1970), education is inherently directive and must always be transformative. But other scholars such as Gottesman, 2013; Young, 2009; 197I; Bowles \& Gintis, 20II; 1976; Bowles, 1972; Illich, 1973; 197I have critically questioned the influence of education. But the work of Bowles and Gintis, especially their correspondence theory, was one of the most sophisticated Marxian social and political thoughts of schooling in the United States. The central focus of the theory is that the outcomes of schooling correspond with the wage labour needs of the economic base (Gottesman, 20I3). It contextualized the production and reception of schooling as being largely a by-product of the intersection of education with other spheres in the capitalist society (Gottesman, 20I3). Similarly, in the 1970s, Ivan Illich, a radical educational theorist in the United States, argued through his book Deschooling Society that schooling should not be confused with learning because the former is a core social control mechanism for the "institutionalization of values" which "leads inevitably to physical pollution, social polarization and psychological impotence, three dimensions in a process of global degradation and modernized misery" (Illich, 197I:I-2). However, Gintis (1972) criticized Deschooling as dangerous but believed that schooling was "creating docile and manipulable consumers for the larger society" (Gintis, 1972:85). He contended that "the social relations of 
education produce and reinforce those values, attitudes and affective capacities which allow individuals to move smoothly into an alienated and class stratified society" (Gintis, 1972:86).

Most Marxist scholars have argued that the hierarchical relations in education lead to alienation which is caused by students' lack of control over their own education. In Nigeria, the educated elite are not only alienated from the educational system; they are also alienated from the masses of their people because of their modernizing thoughts and lifestyles. Herein lies the dilemma of the Nigerian educated elite, products of western education but alienated from their own people! Ayandele (1974) suggested that the best way to understand the educated elite is through "prosopography", which involves collective study of the lives, experiences, strategies and characteristics of main leaders. It is hoped that a detailed study of the biographies of Nigerian leaders and the educated elite will enhance a proper understanding of their strategies to address alienation in order to remain relevant in the society. Although educational attainment is closely related to positive health and retirees' subjective well-being (Li, et al. 20 I3; Fonseca, 2008; Li \& Liang, 2007; Helliwell \& Putnam, 2004; Pinquart \& Sorensen, 2000), higher education is equally related to negative feelings such as disenchantment, disillusion and frustration in retirement (Bowles \& Gintis, 1976; Illich, I97I; Ayandele, 1974; UNFPA \& HAI, 20 22; Russell 2007). This study argues that educational attainment does not only influence opportunities available to retired workers, but also significantly influences income, self-rated health, and life satisfaction in retirement. Education is also a critical predictor of life satisfaction; Hayward, Hardy and Grady (1990) found that older people who were well-educated and in professional jobs were able to keep their jobs and retire later, which enhanced their financial resources and life satisfaction. To retirees with low education, retirement merely reflects and perpetuates cumulative life disadvantages such as poverty and precarious living conditions (Moody 2002). On the other hand, higher paid (white-collar) jobs which often involve sedentary activities have implications for the health and well-being of retirees but this can easily be managed through appropriate health and wellness education. Education equally provides retirees with opportunities to manage lifestyle challenges through awareness, regular exercise and proper diets compared to workers with poor education and socio-economic status who are more likely to be without such awareness and 'resources'.

Life satisfaction is defined as an individual's overall assessment or judgement of thoughts and feelings about life in general based on subjective evaluation of circumstances and experiences in retirement (Seligowki, et al., 2012; Lou, 2010; Diener, 1984). A number of variables contribute to life satisfaction, but this study focused specifically on education as a correlate of life satisfaction among Nigerian retirees in Lagos State. Personal resources such as social support, self-rated health status, extent of functional limitations impact on well-being and life satisfaction in retirement. Life satisfaction also varies across socio-economic and political environments (Oishi, et al. 2009; Pinquart \& Sorensen, 2000) with different factors identified as predictors of well-being in retirement. Correlates of life satisfaction include socio-economic characteristics such as education, financial resources, independence and previously accumulated resources among others (Oishi, et al., 2009; Li \& Liang, 2007). Other scholars (Helliwell \& Putnam, 2004; Pinquart \& Sorensen, 2000) examined the importance of individual characteristics such as socio-economic status, functional independence and health status as well as social networks in determining life satisfaction. Generally, retirees with higher socio-economic status have fewer functional limitations, better health status and are more engaged in social networks and invariably, enjoy higher levels of life satisfaction (Lou, 20I0; Li \& Liang, 2007).

\section{Theoretical framework}

\section{Life course theory of ageing}

Life course theory emphasizes the importance of historical contexts (previous life events) to proper understanding of ageing issues. It argues that the effects of life course events (education) on people's situations in retirement are significantly different for individuals because of their different life cycles, socio-economic status and opportunities among others (Fonseca, 2008; Moody, 2002). Therefore, the experiences of retired people are not necessarily results of a fixed stage in the life course (retirement) but a reflection of their accumulated experiences over the years (Van Solinge 2007; Moen 200I). Thus, the living conditions and life satisfaction of retirees are results of events of previous years, prior to retirement (Amaike, 2009; Elder, 1998). These structural factors also set boundaries and constraints which impinge on the quality of life and life satisfaction of retirees (UNFPA \& HAl, 20 2; Russell, 2007; Waslander, 2007). With this theory, we can infer that the life satisfaction of Nigerian retirees is closely linked to their previous life experiences measured by educational attainment in this study. One major criticism against this theory is that it is broad and it may be difficult to incorporate into a single analysis of the diverse variables associated with old age challenges 
(Price, 2002; Moody, 2002).

\section{Modernization theory of ageing}

The quest to explain the contradictory images of old age in modern society contributed to the emergence of modernization theory of ageing. The socio-economic status of older people improved drastically in stable agricultural societies where land ownership was vested in family heads, usually the oldest members of the family. With the advent of industrialization in the $18^{\text {th }}$ Century, roles of older people were devalued leading to low socio-economic status (Lee and Shaw, 2003). The basic premise of the theory is that the social status of older people and societal development are inversely related. With increasing modernization of society, the roles and status of older people decline because elders have skills, knowledge and wisdom considered obsolete and irrelevant in modern society (Ogunbameru, 2000; Moen, Kim \& Hofmeister 200 I; Cowgill 1974).

The four aspects of modernization which affect ageing population include scientific technology, urbanization, literacy and mass education as well health technology, each of which helps to produce the devalued status of older people in modern society. Although several criticisms trailed the assumptions of modernization theory, some tenets of the theory have since been confirmed in some societies where elders experienced a drastic drop in their social status and relevance as a result of modernization (Cowgill and Holmes 1972; Cowgill 1974; Moody 2002; Kim \& Moen 200I). Older workers with higher education are more likely to have opportunities to remain active in the society (contract employment) than menial workers who are likely to disengage due to obsolete skills or become dependent on family members (Akeredolu-Ale \& Aribiah, 200I; Ogunbameru, 2000). Modernization theory has been accused of Eurocentricism and over-simplification of key concepts such as the status of older people.

\section{Dependence perspective}

On the other hand, the dependence perspective rejects the assumptions of modernization theory. It argues that the development of society can be understood in connection to its historical incorporation into world political-economic systems which affects its adaptation to the requirements of the expansion of the developed (core) countries (Frank, 1972; Rodney, 1972). Dependence perspective addresses the issues of poverty and economic underdevelopment which are seen as by-products of capitalist penetration of the global south which lead to and reproduce unequal development in African countries. African countries are unable to develop old age care systems because of the vicious cycle of dependence perpetuated to reproduce underdevelopment rather than growth (Frank, 1972). Both theories discussed the gaps between developed and underdeveloped societies but differed in terms of the sources of the underdevelopment and the panacea for development and improvement of human conditions.

\section{Theory of intergenerational wealth flows}

Proposed by John Caldwell (1965; 1976), this theory argues for the insurance potential inherent in children's existence expected to be redeemed at a future date, usually in old age. Thus, children are not largely burdens who merely consume resources but they can be sources of old age protection and insurance against life's vicissitudes in the absence of formal social protections in Nigeria. The importance of children in mediating old age challenges becomes compelling with increasing salience of education in ensuring that children are empowered to protect and provide for their ageing parents. Educated children who are better off can indeed help their ageing parents or relatives to meet their basic needs (Caldwell, 1965). Educated children also provide an invigorating new lease of life often borrowed from the towns (cities) which serve as veritable sources of old age insurance and coping strategies in retirement. In essence, having educated children is advantageous to the retirees because it reduces the probability of old age destitution which is more prevalent among childless elderly (Mokomane, 2013; De Vos, 1985; Caldwell, 1980). Therefore, whatever the net deficit in children's labour over consumption, raising children is a rational response to old age risks in the absence of other investments (Caldwell, 1976). Ronald Lee (2000:47) succinctly summarized the point as follows, "in the absence of institutions that provide various kinds of insurance and permit the reallocation through savings of resources to old age, children may still be the best deal around". Poor families often hope to break the poverty jinx and achieve upward mobility through economic returns (income remittances) from large numbers of adult children in the workforce (Mokomane, 2013; Fapohunda \& Todaro, 1988; Cain, 1982, Caldwell, 1980). These social expectations are changing and experiencing tremendous strains because of high rates of unemployment leading to weak filial piety (Mokomane, 20/3). Therefore, the notion of "wealth flows" which rests on the premise that children will support family through their economic contributions and income remittances is grossly inadequate in ensuring economic security in old age. This culminates in old age poverty with many youths unable to discharge expected filial piety (intergenerational supports) 
because of poor or no livelihoods (Mokomane, 2013; Edmondson, 2012; Khagayi, et al. 20II). This study adopts an eclectic theoretical approach to address some identified shortcomings of the theories.

\section{Data and methods}

Data used in this study were extracted from a crosssectional study of predictors of socio-economic well-being of older retirees in Lagos State, Nigeria. The study included formal sector retirees from the Federal, State, Local government areas and organized private sector companies resident in Lagos State. The survey was conducted between January and May, 2007. A stratified multi-stage sample design was used to select 1321 retirees which were covered by means of questionnaires. First, the formal sector was divided into two groups, namely the public and the organized private sector. Second, the public sector was further divided into three levels: Federal, State and local government areas. Third, the retirees were stratified on the basis of socioeconomic and demographic characteristics before selecting the sample. Fourth, the respondents (units of analysis) were selected from the list of pensioners (through pension schedules) with the aid of systematic random sampling method starting from a randomly selected point on the schedule until the last element was chosen. The study sampled between ten and twenty percent of each of the sub-groups in the population which was aimed at ensuring representativeness and fairness to all elements in the population.

This survey research was further complemented by twenty (20) in-depth interview sessions for purposely selected executive members of the Nigerian union of pensioners and pension managers in Lagos State. Two executive members each of the Nigerian Union of pensioners were interviewed in each of the sub-groups namely: University of Lagos \& Federal Radio Corporation of Nigeria retirees (Federal), Lagos State civil service and teaching commission pensioners (State); Shomolu and Ojo retirees (Local government areas) and retirees from selected Nigerian Employers Consultative Association (NECA) member companies. Lastly, one pension manager or staff each was also interviewed except that Lagos State teaching and civil commissions were treated as one group.

\section{Measure}

This study was to assess life satisfaction of formal sector retirees, who were asked to rate their life satisfaction on a 5-point scale (I-very unsatisfied, 2fairly unsatisfied, 3-somewhat satisfied, 4-fairly satisfied, 5-very satisfied). In order to ensure meaningful results, the researcher collapsed the two-unsatisfied responses into low satisfaction and the two-satisfied responses into high satisfaction with the $3^{\text {rd }}$ category being moderate satisfaction.

\section{Dependent variables}

Three domains of dependent variables were covered, namely livelihood adequacy, self-rated health status, and overall satisfaction in retirement which were used in the analysis. Livelihood adequacy was rated on a 5-point scale ranging from very adequate (5) to very inadequate or limited (I). Educational attainment was the independent variable.

Self-rated health status was measured by respondents rating their health status from very poor (I) to very good or excellent (5). Lastly, the respondents were asked to rate their overall satisfaction with life in retirement on a 5-point scale ranging from very unsatisfied (I) to very satisfied (5). A cumulative score for each respondent was obtained by adding the scores on the three key indicators (domains) of life satisfaction. Scores ranged from 4 to 15.

\section{Data analysis}

Univariate and bivariate analyses were used to describe Nigerians retirees' socio-economic and demographic characteristics, livelihood adequacy, and self-rated health and life satisfaction in retirement. Logistic regression was also used to assess predictors of life satisfaction. The statistical significance level for Chi-square and regression analyses was set at less than .05. Analyses were done using SPSS. Content analysis was used to analyze qualitative data (In-depth interviews).

\section{Results}

Tables 1 and 2 below show the socio-economic characteristics of survey respondents. The tables show that majority of the respondents were 60 years old and above. The age distributions are as follows: $60-64$ years (20.7\%), 65 and 69 years (27.2\%) and 70 and 74 years (29.9\%). Majority of the respondents $(87.6 \%)$ had one form of formal education or the other. The minimum educational attainment in this category was primary education (23.5\%); secondary education (30.7\%) while only $10.1 \%$ had no formal education representing retirees who may have worked as cleaners or security officers. The high proportion of respondents with formal education can be attributed to the study population (formal sector retirees) and location of the study, Lagos State which is a cosmopolitan State in the South-West of Nigeria. The study had $64.2 \%$ male and $35.8 \%$ female retirees with $86.5 \%$ of them married and $87.2 \%$ in monogamous unions. More 
than half, $60.6 \%$ were Christians. In terms of $(\$ 250)$. monthly pensions, $30.4 \%$ earned less than NI0, 000 (\$ 62.5) while 6.7\% earned N40, 000 and above

Table I Percentage distribution of socio-demographic characteristics of respondents by sex

\begin{tabular}{|c|c|c|c|}
\hline Characteristics & $\begin{array}{l}\text { Male } \\
N=848\end{array}$ & $\begin{array}{l}\text { Female } \\
N=473\end{array}$ & $\begin{array}{l}\text { Total } \\
N=\mid 32 \text { I }\end{array}$ \\
\hline \multicolumn{4}{|l|}{ Age groups } \\
\hline Less than 55 years & 0.2 & 0.0 & 0.2 \\
\hline 55- 59 years & 12.7 & 18.4 & 14.8 \\
\hline 60- 64 years & 18.8 & 24.3 & 20.7 \\
\hline $65-69$ years & 27.1 & 27.3 & 27.2 \\
\hline 70-74 years & 33.4 & 23.7 & 29.9 \\
\hline $75-79$ years & 5.2 & 4.2 & 4.8 \\
\hline 80 years and above & 0.9 & 1.5 & I.I \\
\hline \multicolumn{4}{|l|}{ Types of marriage } \\
\hline Monogamy & 85.7 & 90.3 & 87.2 \\
\hline Polygamy & 11.5 & 5.8 & 9.6 \\
\hline No response & 2.8 & 3.9 & 3.1 \\
\hline \multicolumn{4}{|l|}{ Educational attainment } \\
\hline No formal education & 9.8 & 10.8 & 10.1 \\
\hline Primary Education & 23.3 & 23.9 & 23.5 \\
\hline Secondary Education & 31.8 & 28.8 & 30.7 \\
\hline NCE/OND Degree & 12.4 & 16.9 & 14.0 \\
\hline First Degree & 14.7 & 13.3 & 14.2 \\
\hline Masters Degree & 4.0 & 4.2 & 4.1 \\
\hline Doctoral Degree & 1.3 & 0.4 & 1.0 \\
\hline Can't say & 1.4 & 0.4 & I.I \\
\hline \multicolumn{4}{|c|}{ Nature of last employment } \\
\hline Managerial & 25.9 & 22.6 & 24.8 \\
\hline Teaching & 8.1 & 14.6 & 10.4 \\
\hline Bureaucratic & 65.9 & 62.8 & 64.8 \\
\hline Total & 100.0 & 100.0 & 100.0 \\
\hline
\end{tabular}


African Population Studies Vol 27, 2 Supp (Mar 2014)

Table 2 Percentage distribution of respondents by socio-economic characteristics by sex

\begin{tabular}{|c|c|c|c|}
\hline Characteristics & $\begin{array}{l}\text { Male } \\
N=848\end{array}$ & $\begin{array}{l}\text { Female } \\
N=473\end{array}$ & $\begin{array}{l}\text { Total } \\
N=|32|\end{array}$ \\
\hline \multicolumn{4}{|l|}{ Religion } \\
\hline Christianity & 59.6 & 62.4 & 60.6 \\
\hline Islam & 38.0 & 34.7 & 36.8 \\
\hline Traditional Religion & 0.9 & 1.1 & 1.0 \\
\hline Other religious affiliations & 0.7 & 0.4 & 0.6 \\
\hline Can't say & 0.8 & 1.3 & 1.0 \\
\hline \multicolumn{4}{|l|}{ Marital Status } \\
\hline Single & 2.2 & 2.1 & 2.2 \\
\hline Married & 90.0 & 80.3 & 86.5 \\
\hline Separated & 3.4 & 4.2 & 3.7 \\
\hline Divorced & 1.7 & 4.0 & 2.5 \\
\hline Widowed & 2.6 & 9.1 & 2.5 \\
\hline Can't say & 0.1 & 0.2 & 0.2 \\
\hline \multicolumn{4}{|l|}{ Ethnic Groups } \\
\hline Yoruba & 69.9 & 71.9 & 70.6 \\
\hline Hausa/ Fulani & 5.5 & 6.6 & 5.9 \\
\hline Igbo & 16.7 & 18.0 & 17.2 \\
\hline Other ethnic groups & 6.0 & 3.0 & 4.9 \\
\hline Can't say & 1.8 & 0.6 & 1.4 \\
\hline \multicolumn{4}{|l|}{$\begin{array}{l}\text { Monthly Pensions } \\
\text { in Naira }\end{array}$} \\
\hline Less than NI0, 000 & 31.6 & 28.1 & 30.4 \\
\hline NI0, $000-15,000$ & 17.1 & 18.8 & 17.7 \\
\hline $\mathrm{N} 15,00 \mathrm{I}-\mathrm{N} 20,000$ & 13.1 & 12.7 & 12.9 \\
\hline $\mathrm{N} 20,00 \mathrm{I}-\mathrm{N} 25,000$ & 9.9 & 10.1 & 10.0 \\
\hline $\mathrm{N} 25,00 \mathrm{I}-\mathrm{N} 30,000$ & 8.3 & 9.7 & 8.8 \\
\hline $\mathrm{N} 30,00 \mathrm{I}-\mathrm{N} 35,000$ & 3.4 & 3.2 & 3.3 \\
\hline $\mathrm{N} 35,00 \mathrm{I}-\mathrm{N} 40,000$ & 3.9 & 3.0 & 3.6 \\
\hline $\mathrm{N} 40,00 \mathrm{I}$ and above & 6.5 & 7.2 & 6.7 \\
\hline Can't say & 6.3 & 7.2 & 6.6 \\
\hline Total & 100.0 & 100.0 & 100.0 \\
\hline
\end{tabular}


Table 3 Composite measure of life satisfaction in retirement by educational attainment

\begin{tabular}{|c|c|c|c|c|c|c|}
\hline & & & \multicolumn{3}{|c|}{ Satisfaction in Retirement } & \multirow[t]{2}{*}{ Total } \\
\hline & & & Low satisfaction & $\begin{array}{l}\text { Moderate } \\
\text { satisfaction }\end{array}$ & $\begin{array}{l}\text { High } \\
\text { satisfaction }\end{array}$ & \\
\hline \multirow[t]{10}{*}{ Educational attainment I } & None & Count & 36 & 95 & 3 & 134 \\
\hline & & $\begin{array}{l}\% \text { within } \\
\text { Educational } \\
\text { qualification }\end{array}$ & $26.9 \%$ & $70.9 \%$ & $2.2 \%$ & $100.0 \%$ \\
\hline & \multirow[t]{2}{*}{ Primary Education } & Count & 141 & 163 & 7 & 311 \\
\hline & & $\begin{array}{l}\% \text { within } \\
\text { Educational } \\
\text { qualification }\end{array}$ & $45.3 \%$ & $52.4 \%$ & $2.3 \%$ & $100.0 \%$ \\
\hline & \multirow{2}{*}{$\begin{array}{l}\text { Secondary } \\
\text { Education }\end{array}$} & Count & 152 & 242 & 28 & 422 \\
\hline & & $\begin{array}{l}\% \text { within } \\
\text { Educational } \\
\text { qualification }\end{array}$ & $36.0 \%$ & $57.3 \%$ & $6.6 \%$ & $100.0 \%$ \\
\hline & \multirow[t]{2}{*}{ Tertiary } & Count & 103 & 252 & 85 & 440 \\
\hline & & $\begin{array}{l}\text { \% within } \\
\text { Educational } \\
\text { qualification }\end{array}$ & $23.4 \%$ & $57.3 \%$ & $19.3 \%$ & $100.0 \%$ \\
\hline & \multirow[t]{2}{*}{ No response } & Count & 4 & 5 & 5 & 14 \\
\hline & & $\begin{array}{l}\% \text { within } \\
\text { Educational } \\
\text { qualification }\end{array}$ & $28.6 \%$ & $35.7 \%$ & $35.7 \%$ & $100.0 \%$ \\
\hline \multirow{2}{*}{\multicolumn{2}{|c|}{ Total }} & Count & 436 & 757 & 128 & 1321 \\
\hline & & $\begin{array}{l}\text { \% within } \\
\text { Educational } \\
\text { qualification }\end{array}$ & $33.0 \%$ & $57.3 \%$ & $9.7 \%$ & $100.0 \%$ \\
\hline
\end{tabular}

$\mathrm{X}^{2}=117.525, \mathrm{df}=8, \mathrm{P}<.001$ ****

Table 3 shows the composite measure of life satisfaction by educational attainment using three indicators namely, assessment of livelihood adequacy, selfrated health and overall satisfaction with life in retirement. Composite measure of life satisfaction shows that life satisfaction was significantly related to education, self-rated health, livelihood adequacy and overall satisfaction. The measure reveals a statistically significant relationship which means that more retirees with tertiary education reported high satisfaction with life $(19.3 \%)$ than their counterparts with no formal education $(2.2 \%)$ or primary education $(2.3 \%)$. Interestingly, all retirees irrespective of their educational attainment rated their levels of life satisfaction in retirement low. But, there were more retirees with no formal education $(26.9 \%)$ in this category than retirees with tertiary education (23.4\%). This shows that education is one of the main predictors of life satisfaction in retirement.

Table 4 Logistic regression is used to buttress statistical analysis earlier discussed.

Table 4 Logistic regression of correlates of life satisfaction in retirement

\begin{tabular}{llll}
\hline Variable & Coefficient (B) & Standard Error (S.E.) & Odds Ratio (Exp. B) \\
\hline Sex & & & 1.00 \\
Male (RC) & - & - & 1.029 \\
Female & 0.028 & 0.98 & 1.00 \\
\hline Age & - & & 4.681 \\
Less than 55 years & 1.543 & 5.460 & 7.224 \\
$55-59$ years & 1.977 & 5.458 & 8.008 \\
$60-64$ years & 2.080 & 5.457 & 6.303 \\
$65-69$ years & 1.841 & 5.458 & 2.545 \\
$70-74$ years & 0.934 & 5.473 & 4.197 \\
$75-79$ years & 1.434 & 5.506 & 0.007 \\
80 years and above & -4.909 & 12.859 &
\end{tabular}




\begin{tabular}{llll}
$\begin{array}{l}\text { Employment Category } \\
\text { Organized .Private (RC) }\end{array}$ & - & - & 1.00 \\
Public & -1.814 & 0.163 & $0.25 I^{* * *}$ \\
Marital Status & - & - & 1.00 \\
Single & 1.103 & 6.767 & 3.013 \\
Married & 1.239 & 6.778 & 3.453 \\
Separated & 0.594 & 6.784 & 1.812 \\
Divorced & 1.195 & 6.773 & 3.304 \\
Widowed & -5.076 & 33.823 & 0.006 \\
Can't Say & & & 1.00 \\
\hline Educational Qualification & - & - & 0.777 \\
None & -0.253 & 0.284 & 1.071 \\
Primary & 0.068 & 0.242 & $2.36 I^{* * *}$ \\
Secondary & 0.859 & 0.227 & 1.056 \\
Tertiary & 0.054 & 0.665 & \\
Can't Say & &
\end{tabular}

Notes: *P $<0.05,{ }^{*} * \mathrm{P}<0.01$, *** $\mathrm{P}<0.00$ I

The logistic regression for predictors of life satisfaction in retirement was carried out. Some variables were tested but only tertiary educational attainment and employment category were found to be very significant in influencing likelihood of having adequate livelihood and being satisfied in retirement. Specifically, retirees with tertiary educational qualifications were two times more likely to have adequate livelihood compared to other educational categories and therefore more satisfied with life in retirement. Retirees from the organized private sector were also found to be more likely to have adequate retirement livelihood and higher life satisfaction than their counterparts in the public sector. Nevertheless, nature of last employment was found to be marginally significant in predicting adequacy of livelihood and life satisfaction in retirement, with bureaucrats being less likely to have adequate livelihood and being satisfied in retirement. These logistic regression models further strengthen and validate the results of Pearson Chi-square.

\section{Discussion}

Using a relatively representative sample of retirees in Lagos State, this study examined the importance of education as a predictor of life satisfaction among Nigerian retirees. The study showed that educated retirees were more satisfied with their lives in retirement than illiterate retirees. Consistent with previous studies (Hooyman \& Kiyak, 2010; Oishi, et al., 2007; Li \& Liang, 2007), livelihood adequacy, selfrated health status and educational attainment were associated with life satisfaction among Nigerian retirees in Lagos State, Nigeria. Although majority of respondents $(57.3 \%)$ rated their life satisfaction as moderate, there were more educated retirees with high levels of life satisfaction. In essence, educational attainment influenced life satisfaction with more educated retirees (19.3\%) reporting high satisfaction with life in retirement compared to retirees with no formal education $(2.2 \%)$ and retirees with primary education (2.3\%). These results reflect the importance of socio-economic status (education) in influencing well-being and life satisfaction in retirement. Since health status is a universal source of concern to older retirees, this study assessed its impact on functional ability in carrying out activities of daily living (ADLs). Retirees with poor health status reported lower life satisfaction because health status impacts life satisfaction (Hooyman \& Kiyak, 2010). This is because poor education affects key indicators of well-being in retirement such as financial status (livelihood adequacy), health status and overall satisfaction which negatively affects sense of independence, competence and life satisfaction ( $\mathrm{Li}$ \& Liang, 2007; Ogunbameru, 2000; Pinquart \& Sorensen, 2000).

From the data analysis, educational attainment was directly related to health status, livelihood adequacy and subjective well-being (overall satisfaction). Retirees with post primary education had better indicators of standard of living (health status, adequacy of livelihood to meet basic needs, living standards and higher satisfaction with living conditions) compared to retirees with no formal education or primary education. All statistical tests show statistically significant relationships between educational attainment and life satisfaction among older retirees through Pearson Chi-square and Logistic regression. Qualitative data from pension managers and staff also buttressed the fact that retirees with higher education were able to transit to other roles in their communities (as opinion leaders, educators/teachers, leaders and consultants) which provided opportunities to remain socially relevant and satisfied in retirement. The less educated retirees often with little or no valued social resources had difficulty in adjusting to changes in their roles and status, hence were less satisfied in retirement. Although education is an important determinant of life chances and opportunities, its elasticity may be overstretched leading to gaps between perceived opportunities 
and actual opportunities (socio-economic wellbeing) in later life (Fujita and Diener, 2005; Blanchflower and Oswald, 2004).

From the study findings, we can deduce that education helps to mediate the challenges associated with retirement but this effect may be 'elastic'. Hence, once the 'elasticity' of education is stretched beyond its limit, there will be dire consequences for retirees in Lagos State, Nigeria. This clearly shows that educated retirees who are unemployed or over burdened by family responsibilities may experience more disappointments in retirement than their uneducated counterparts who do not have such challenges. The qualitative data also corroborate the findings with majority of executive members of Nigerian union of pensioners clearly in support of the fact that although education helped retirees to meet their basic needs, some educated retirees still had difficulty in discharging their responsibilities as breadwinners in their homes. This means that the impact of education on experienced utility (life satisfaction) begins to decline after compulsory education leading to regret or frustration in later life largely due to gaps between perceived opportunities (aspirations) and actual or subjective opportunities provided by educational attainment.

This study has some limitations. The survey was cross-sectional in nature. The relationships in this study are non-directional. It is possible for some educated retirees to report dissatisfaction with life in their quest to meet their high taste which may strain their modest income, undermine their well-being and lower their life satisfaction. Longitudinal data are often required to determine these reciprocal relationships. Secondly, the study provided only general profile and characteristics of older retirees' life satisfaction with particular focus on randomly selected populations in Lagos State. A more comprehensive and national study will address specific variations which will provide insights and directions for policy and retirement planning in Nigeria. Despite the limitations, the findings of this study have direct relevance and implications for policy thrust and development initiatives in ensuring adjustment to retirement in Lagos State, Nigeria.

\section{Conclusion}

Education was found to be a major stabilizing factor in adjusting to life challenges in retirement. Most retirees who assessed their life satisfaction as high were retirees with higher (tertiary) education. This clearly shows that educated retirees are more likely to have adequate livelihood, better health status and report higher life satisfaction in retirement than retirees with low educational attainment. This is because education assists in equipping older people with skills and resources with which to adjust to changes in their socio-economic status in retirement. In general, the study findings buttress the pivotal role of education as a predictor of life satisfaction among older retirees in Lagos State without failing to point out the 'elasticity' of the transformative power of education.

The paper concludes with the following recommendations:

- Since education is a critical determinant of well-being in retirement, employers of labour should ensure that their workers engage in continuous improvement of their life skills through educational advancement and on-thejob-training.

- The three tiers of government should develop social protection programmes which will provide income assistance or monetary supports and free health insurance to Nigerians in retirement (old age).

- There is need for legislations on appropriate compensations for workers which will reduce pervasive poverty after paid employment.

- Retirement benefits should be promptly paid (as first charge) to retirees in order to minimize frustration and provide opportunities for active retirees to remain engaged in the society.

- The negative impact of ageing process (retirement) can be minimized through strengthening the informal social supports (adult children) through employment opportunities and skills acquisition.

\section{Acknowledgements}

The author hereby acknowledges CODESRIA and Kennesaw State University, Atlanta Georgia, USA for their financial and material support of this Ph.D. research.

\section{References}

Akeredolu-Ale, E.O and Aribiah, O. 200I. Public Policy and Old-Age Security in Nigeria. Ibadan: Center for Social Policy.

Alkire, S. and Foster, J. E. 20 I I. 'Counting and Multidimensional Poverty Measurement' Journal of Public Economics, 95(7-8):476-487.

Amaike, G.O. 2009. Livelihood and Living Conditions of Formal Sector Retirees in Lagos State, Nigeria. Unpublished Ph.D. Thesis. Lagos: Department of Sociology and School of Postgraduate Studies, University of Lagos, Lagos State, Nigeria.

Alpas, F. et al. 2000. 'Contribution of retirementrelated variables to well-being in an older male sample'. New Zealand Journal of Psychology, 29: 74-79. 
Atchley, R.C. 1985. Social Forces and Ageing: An Introduction to Social Gerontology $4^{\text {th }}$ Ed. Belmont, California: Wadsworth.

Ayandele, E.A. 1974. The Educated Elite in the Nigerian Society: University Lecture. Ibadan: Ibadan University Press.

Bender, K.A. and Jivan, N.A.2005. 'What Makes Retirees Happy?' An issue in brief. Center for Retirement Research. Boston College. February, 2005. No. 28: I-8.

Blanchflower, D.G. and Oswald, A. J. 2004. 'Wellbeing Over Time in Britain and the USA' Journal of Public Economics, 88(7-8): I359-I 386.

Bowles, S. 1972. 'Unequal Education \& the Reproduction of the Social Division of Labour' in Schooling in Corporate Society: the Political Economy of Education in America. Carnoy, M. (Ed.) New York: David McKay.

Bowles, S. and Gintis, H. 20I I. Schooling in Capitalist America: Educational Reform \& the Contradictions of Economic Life. Chicago: Haymarket Books.

Bowles, S. and Gintis, H. 1976. Schooling in Capitalist America: Educational Reform \& the Contradictions of Economic Life. New York: Basic Books.

Cain, M. 1982. 'Perspectives on Family \& Fertility in Developing Countries' Population Studies, 36(2): I52-175.

Calasanti, T. 1996. 'Gender and Life Satisfaction in Retirement: an Assessment of the Male Model'. Journal of Gerontology, Gerontology Social Science, 5I:5I8-529.

Caldwell, J.C. 1965. 'Extended Family Obligation and education: A Study of an Aspect of Demographic Transition among Ghanaian University Students' Population Studies, 19(2): 183-199.

------ 1976. 'Towards a Restatement of Demographic Transition Theory' Population \& Development Review, 2(3/): 32I-366.

----- 1980. 'Mass Education as a Determinant of the Timing of Fertility Decline' Population \& Development Review 6:225-255.

Cumming, E. and Henry, W. I 96I. Growing Old: The Process of Disengagement. New York: Basic Books.

Cowgill, D.O. and Holmes, L.D. 1972. Ageing and Modernization. New York: Appletton- CenturyCrofts.

Cunha, F. and Heckman, J. J. 2007. 'The Technology of Skill Formation' American Economic Review, 97(2):3 I-47.

De Vos, S. 1985. 'An Old Age Security incentive for children in the Philippines \& Taiwan' Economic Development \& Cultural Change, 33(4): 793-8I4.

Edmondson, R. 2012. 'Intergenerational Relations in the West Ireland \& Socio-cultural approaches to wisdom' Journal of family Issues, 33(II): 76-98.
Cambridge: Sage.

Diener, E. 1984. "Subjective well-being". Psychological Bulletin, 95:542-575.

Elder, G.H. Jr. 1998. 'The Life Course Paradigm: Social Change and Individual Development' In Moen, P., Elder, G.H. Jr. and Luscher, K. (Eds.), Examining Lives in Context: Perspectives on the Ecology of Human Development. Washington, DC: American Psychological Association: I0I-I 39.

Fapohunda, E.R. and Todaro, M.P. 1988. 'Family Structure, Implicit Contracts \& the Demand for Children in Southern Nigeria', Population \& Development Review, I4(4): 57I-594.

Fonseca, A.M. 2008. 'Determinants of Successful Retirement in a Portuguese Population' Clinical Gerontology, 17:219-224. Cambridge: University Press.

Frank, A.G. 1972. 'The Development of Underdevelopment' in Cockcroft, J.D; Frank, A.G. \& Johnson, D. (Eds.) Dependence \& Underdevelopment. Garden City, New York: Anchor Books.

Freire, P. 1996. Pedagogy of the Oppressed (M. Bergman Ramos, Trans.) London: Penguin.

Freire, P. 1970. Pedagogy of the Oppressed. Translated by Myra Bergman Ramos. New York: Continuum.

Fujita, F. and E. Diener, 2005. 'Life Satisfaction Set point: Stability and Change'. Journal of Personality and Social Psychology, 88(I): I58-164.

Gintis, H. 1972. 'Toward a Political Economy of Education: A Radical Critique of Ivan Illich's Deschooling Society' Harvard Educational Review, 42:70-96.

Gottesman, I. 2013. 'Socialist Revolution: Samuel Bowles, Herbert Gintis and the Emergence of Marxist Thought in the field of Education, Educational Studies'. Journal of the American Educational Studies Association, 49 (I): 5-3I.

Hayward, M.D., Hardy, W.R., and Grady, W.R. 1990. 'Work and retirement among a cohort of older men in the United States, 1966-1983'. Demography, 27: 337-356.

Heckman, J.J.; Stixrud, J. and Urzua, S. 2006. 'The Effects of Cognitive and Non-cognitive Abilities on Labour Market Outcomes and Social Behaviour' Journal of Labour Economics. 24(3):4II-82.

Helliwell, J. and Putnam, R. 2004. 'The Social Context of Well-being. Philosophical Transactions' Royal Society of London B, 359, |435- I 446.

Hooyman, N.R. and Kiyak, H.A. 20I0. Social Gerontology: A Multidisciplinary Perspective. Upper saddle River: Prentice Hall.

Illich, I. 1973. Deschooling Society. London: Penguin. 
Illich, I. 197I. Deschooling Society. New York: Harrow Books.

Khagayi, S. et al., 20I I. 'Socioeconomic Status and the Elderly Adult Mortality in Rural Ghana: Evidence from the Navrongo DSS' African Population Studies Journal, 25 (I) (African Dissertation Series, Vol. I): I- 6.

Kim, J.E. and Moen, P. 200I. 'Is Retirement Good or Bad for Subjective Well-being? Current Directions in Psychological Science', 10 (3), June 2001:83-86. American Psychological Association: Blackwell Publishers Inc.

Lee, R.B.2000. 'Intergenerational Transfers \& the Economic Life Cycle: A Cross-cultural Perspective' in Mason, A., and Tapinos, G. (Eds.) Sharing the Wealth: Demographic Change \& Economic Transfer between Generations. Oxford: Oxford University Press: I7-56.

Lee, S. and Shaw, L. 2003. Gender and Economic Security in Retirement. Institute for Women's policy Research, Washington, D.C. http:/ www.iwpr.org Retrieved in May, 2012.

Li, H. et al. 2013. 'Life Satisfaction of Older Chinese Adults living in Rural Communities'. Journal of Cross-cultural Gerontology, 28: I53-165.

Li, L.W. and Liang, J. 2009. 'Social Exchange \& Subjective Well-being among Older Chinese: Does Age Make a Difference?' Psychology \& Ageing, 22:386-391.

Lou, V.W.Q.2010. 'Life Satisfaction of Older Adults in Hong Kong: The Role of Social Support from Grandchildren' Social Indicators Research, 95(3): 377-391.

Moen, P. 200I. 'The Gendered Life Course' in Binstock, R.H. and George, L.K. (Eds.) Handbook of Ageing and the Social Sciences. $5^{\text {th }}$ Edition. New York: Academic Press.

Mokomane, Z. 2013. 'Social Protection as a Mechanism for Family Protection in Sub-Saharan Africa' International Journal of Social Welfare, 22:248-259.

Moody, H.R. 2002. Ageing: Concepts and Controversies. $4^{\text {th }}$ edition. Sage Publication.
United States: Pine Forge Press.

Ogunbameru, O.A. 2000. 'Attitudes to Work and Retirement among Academic Staff of Nigerian Universities'. African Journal of Research in Education. I, ( I): 885-88.

Oishi, et al 2009. 'Cross-cultural Variations in Predictors of Life Satisfaction: Perspectives from Needs and Values'. Social Indicators Research Series, 38: 109-127.

Pinquart, M. \& Sorensen, S. 2000. 'Influence of Socio-economic Status, Social Networks \& Competence on Subjective Well-being in Later life: a Meta analysis'. Psychology \& Ageing, I 5: I87224.

Price, C.A. 2002. 'Retirement for Women: The Impact of Employment'. Journal of Women and Ageing, I4 (3/4):4I -57.

Rodney, W. 1972. How Europe Underdeveloped Africa. London: Bogle-L'Ouverture Publications

Russell, C. 2007. 'What Do Older Women and Men Want?: Gender Differences in the "Lived" Experiences of Ageing'. Current Sociology, 3 (55): 173-192.

Seligowski, A.V. et al. 20I2. "Correlates of life Satisfaction among Ageing Veterans" Applied Psychology: Health \& Well-being, 4(3):26I-275.

UNFPA \& Help Age International. 20 I2. Ageing in the Twenty-First Century: A Celebration and A challenge. New York and London: UNFPA \& HAI

Van Solinge, H. 2007. 'Health Change in Retirement: A Longitudinal Study among Older Workers in the Netherlands' Research on Ageing, 29: 225256.

Waslander, B. (2007) 'Transitions to retirement and the timing of pension benefit take-up'. a paper by Informetrica Limited, Ottawa, Ontario, Canada.

Young, M. 2009. 'What are schools for?' in Lauder, H., Porter, J. and Daniels, H. (Eds.) Critical Perspectives on Education, London: Routledge.

Young, M. 1971. Knowledge and Control: New Directions for the Sociology of Education. London: Collier-Macmillan. 